\title{
Impact of Nanotechnology Themed Learning Community (TLC) Program in Freshmen Engineering
}

\section{Dr. Mangilal Agarwal, Indiana University-Purdue University Indianapolis}

Mangilal Agarwal received his B.E. degree in Electronics and Communication Engineering from Osmania University (Hyderabad, India) in 1998, and the M.S. and Ph.D. in Engineering from Louisiana Tech University (Ruston, LA) in 2002 and 2004, respectively. Upon receiving his Ph.D. degree, he was employed by Louisiana Tech University, as a Postdoctoral Research Associate, followed by appointments as Research Staff and Research Assistant Professor at the Institute for Micromanufacturing, the largest campus-wide interdisciplinary research institute. Currently he is the Interim Director of the Integrated Nanosystems Development Institute (INDI), Associate Director for Research Development at Office of Vice Chancellor for Research (OVCR), and Adjunct Associate Professor in the Electrical and Computer Engineering Department at Indiana University - Purdue University Indianapolis (IUPUI) (Indianapolis, IN), and directs the development of interdisciplinary research and education initiatives.

\section{Dr. Maher E. Rizkalla, Indiana University-Purdue University, Indianapolis}

Maher Rizkalla received his Ph.D. in Electrical and Computer Engineering from Case Western Reserve University in 1985. From January 1985 to September 1986, he was employed as a Research Scientist at Argonne National Laboratory, Argonne, IL, and an Assistant Professor at Purdue University Calumet until September 1986. Then, he joined the Department of Electrical and Computer Engineering at IUPUI where he is now Professor and Associate Chair of the Department. His research interests include solid State devices, VLSI signal processing, and electromagnetics. He is a senior member of IEEE and a PE registered in the State of Indiana.

\section{Dr. Sudhir Shrestha \\ Dr. Kody Varahramyan, IUPUI}

Dr. Kody Varahramyan received his Ph.D. in Electrical Engineering from Rensselaer Polytechnic Institute in 1983. From 1982 to 1992 he was with IBM Microelectronics, conducting research and development in the realization of advanced semiconductor technologies. From 1992 to 2008 he was with Louisiana Tech University, where he was the Entergy/LP\&L/NOPSI Professor of Electrical Engineering, in recognition of his teaching and research contributions in the microsystems and nanotechnology areas. From September 2000 to June 2008 he was the Director of the Institute for Micromanufacturing, where, from 1992, he had contributed to the growth and development of the Institute, including through planning and setting up of laboratory resources and facilities, development and implementation of major sponsored research efforts, and realization of academic courses and curricula, on the science and engineering of materials, processes, and devices for the realization of micro/nanoscale systems. Since July of 2008, he has been the Vice Chancellor for Research at Indiana University - Purdue University Indianapolis, where he has been responsible for the advancement of research and scholarly activities, including interdisciplinary research programs that address important national and global needs. 


\title{
Impact of nanotechnology themed learning community (TLC) program in freshmen engineering
}

\author{
Integrated Nanosystems Development Institute (INDI), Indiana University-Purdue University \\ Indianapolis (IUPUI), Indianapolis, IN
}

\begin{abstract}
A new Bachelor of Science track in Nanotechnology (Nanotechnology Track) has been developed at the School of Engineering and Technology at Indiana University Purdue-University Indianapolis (IUPUI). Within this track, a cohort of 25 freshman engineering students from Electrical \& Computer Engineering (ECE) and Mechanical Engineering (ME) participated in a nanotechnology Themed Learning Community (TLC) program. In this program, the students enroll and progress simultaneously in a group of three strategically connected freshman engineering courses with a nanotechnology theme (Introduction to Engineering, Introduction to Engineering Profession, and Fundamentals of Speech Communication). TLC faculty members closely worked with each other to coordinate teaching and learning efforts that reflect the goals of the developed nanotechnology track.

This paper presents the components of the developed and implemented TLC program including details of the courses and assessment data, showing the impact on freshman engineering students in nanotechnology education. Comparative assessment data show, 20\% higher freshman retention in the TLC cohort than the traditional group, which highlights the impact of the TLC program on freshman engineering students in nanotechnology education. Data also shows that the TLC (three courses) has guided over 75\% of the students towards interests in nanotechnology tracks and research, and over $90 \%$ of the students indicate that they are enjoying the multidisciplinary activities of the program. This may be attributed to the "attached learning" when incorporating nanotechnology into real engineering applications, such as renewable energy, medicine, quantum computers, and many others.
\end{abstract}

\section{Introduction}

Nanotechnology is a rapidly advancing field that shows promise in solving current science and technology challenges through the innovative materials, processes \& devices, and their applications. Nanomanufacturing, including self-assembly, has become an important tool in developing nanoscale devices applicable in medicine, electronics, and energy. Nanomaterials such as carbon nanotubes, graphene, quantum dots, and nanoparticles are of particular interest in sensor technologies, electronics, and other devices to meet the US industrial challenges. It is a field of emerging technologies, multidisciplinary in nature, encompassing many engineering and science disciplines, including physics, biology, chemistry, and biomedical, electrical, mechanical, and materials engineering. ${ }^{1-5}$ Given the diverse nature of the nanotechnology field, a class of multidisciplinary students combined into a nanotechnology course, shows great potentials of enhancing the integration of engineering/science knowledge and the learning experience of the students in the meaningful way. The goals of this new program are to design a multidisciplinary research-based curriculum for nanotechnology track that prepares students to enter the local, national, and global workforce and become leaders of research and development 
in industry, businesses, and academia in the emerging era of nanotechnology. The goals of this track follows the trend of Engineering 2020 in designing an engineering curriculum that grows to meet or exceed current and future engineering demands. This is based on vision, values, variability, knowledge and awareness of the inherent worth of people. ${ }^{6}$ Developing engineering curricula and educating students to meet the industry challenges were presented previously. ${ }^{7-10}$ This paper presents the assessment results of TLC program within a newly developed nanotechnology track within ECE and ME programs.

\section{Nanotechnology Track}

IUPUI Purdue School of Engineering and Technology has developed and implemented a new program that incorporates a research-based academic nanotechnology track. The Integration of Nanotechnology in Engineering Curriculum program (the IUPUI "INEC"), defined by the nanotechnology track, is integrated into the established degrees including Bachelor of Science in ECE and ME degree programs. ${ }^{11-12}$ INEC brings together students/faculty collaborative research and academic teams to provide undergraduate students with curricula based on both research and education in nanotechnology. A diagram that depicts the ideas of the implemented nanotechnology track is shown in Figure 1.

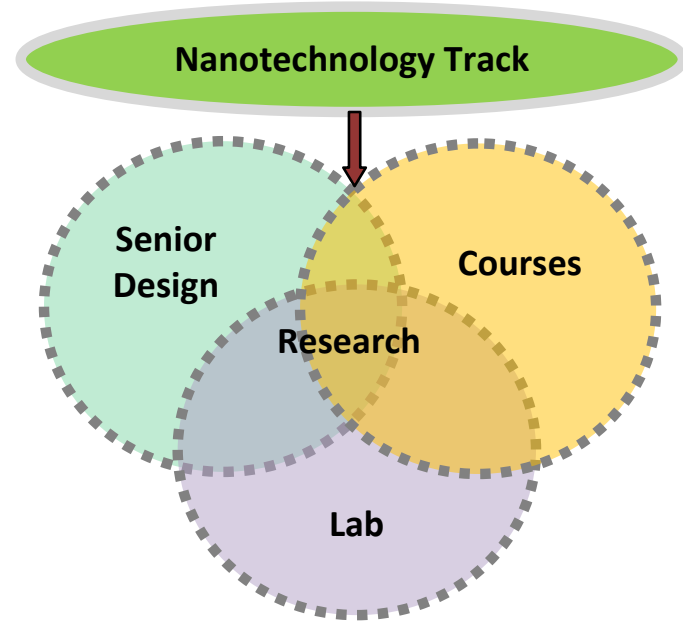

Fig. 1: A schematic diagram representing the ideals of the nanotechnology track.

The nanotechnology track implemented at IUPUI represents a powerful pedagogical approach to comprehensively integrate nanotechnology into the curricula within the engineering degree programs. During the freshman year, students from ECE and ME departments are introduced to various modules of nanotechnology through Theme Learning Communities (TLCs) (IUPUI's TLC program was awarded the 2008 Outstanding Student Retention Program Award by the Educational Policy Institute). In the first semester to form TLC, a cohort of 25 students are concurrently enrolled by the IUPUI Registrar to introductory courses in engineering, Introduction to Engineering (ENGR 196), Introduction to Engineering Profession (ENGR 195), and Fundamentals of Speech Communications (COMM R110). The high quality delivery of the IUPUI's TLC programs has had a great impact on this track. In addition to the nanotechnology modules integrated into the freshman engineering, new interdisciplinary sophomore-, junior-, and senior-level nanotechnology-based courses are introduced within the curriculum for students 
in the nanotechnology track. These new courses serve as technical electives for the traditional ECE and ME degree programs keeping the same overall required credit hours.

\section{Theme Learning Community}

The TLC consists of a cohort of students progressing simultaneously at the freshman level, taking freshman and general education courses together. The fall semester TLC includes at least one section (a cohort of 25 students) of Introduction to Engineering, Introduction to Engineering Profession, and Fundamentals of Speech Communication courses connected with a nanotechnology theme (shown in Table I). The goal of the TLC includes hands-on laboratory and research experiences in the emerging nanotechnology area. Examples of assigned freshman engineering projects include solar cell and fuel cell cars. In these labs students assemble a model car and use solar panel and fuel cell to power the cars. A series of experiments that student conduct include measurement of open and short circuit current and efficiency of solar panel, and performance of the car with varying light intensity. In the fuel cell car project, students use solar panel for the electrolysis of water and use the generated hydrogen and oxygen as fuel to power the car using a fuel cell device. Students conduct a series of experiments with the fuel cell that include measurement of electrolysis and fuel cell efficiencies. These laboratories provide students with firsthand experience on renewable energy and impact of nanotechnology in the future energy device. The laboratories were conducted within the facilities provided by the nanotechnology institute. However, many of these experiments can be realized in a setting where such facilities are not easily accessible. For example, nanoscale properties manifestation can be conducted by simply building a composite of commercially available polymer materials and carbon nanotubes. Many of the simulation tools are freely available through website such as nanoHUB.org. Similarly, the kits needed for solar cell and fuel cell cars are commercially available at reasonable costs. These projects can be conducted in a classroom or in a wet laboratory by a team of 4-6 students.

Seven credit hours incorporate fundamental, practical and computational principles of nanotechnology into the curriculum. This will allow the TLC to build the following professional attributes:

- Ability to work productively in a collaborative setting.

- Knowledge of successful careers in the nanotechnology area to fill the future needs of industry. Students pursuing this track are equipped with key elements needed in industry, including computer modeling and simulation, laboratory experience, and design methodologies.

- Ability to do scientific research and engage in discovery and scholarship.

- Develop strong professional attributes, including ethical behavior in the workplace, understanding of societal responsibility, and positive attitudes about themselves that encourage engagement in continuing professional development and confidence about their future careers in nanotechnology.

- Good oral and written communication skills. 
TABLE I: An example for the TLC within a semester, the cohort is enrolled in the following courses.

\begin{tabular}{|c|c|c|}
\hline \multicolumn{3}{|c|}{ Freshman Year } \\
\hline ENGR 195 & $\begin{array}{l}\text { Introduction to } \\
\text { Engineering } \\
\text { Profession }\end{array}$ & $\begin{array}{l}\text { This course introduces students to the engineering profession and } \\
\text { to campus resources. The course is designed to help students } \\
\text { develop essential communication, critical thinking, and time- } \\
\text { management skills needed for collaboration. Discussions include } \\
\text { study in electrical, computer, mechanical, and bioengineering. } \\
\text { New discussions and seminars include information of } \\
\text { nanotechnology track and how it connects to various science and } \\
\text { engineering professions in academia and industry. }\end{array}$ \\
\hline ENGR 196 & $\begin{array}{l}\text { Introduction to } \\
\text { Engineering }\end{array}$ & $\begin{array}{l}\text { The course will introduce the definition of nanoscale and } \\
\text { applications of nano-materials, -devices, and -systems in energy, } \\
\text { medicine, defense, information technology, and consumer } \\
\text { products. The hands-on project for the class includes (1) } \\
\text { assembly and testing of solar cell and fuel cell car kit and (2) } \\
\text { Fabrication and testing of dye-synthesized solar cells. }\end{array}$ \\
\hline COMM R110 & $\begin{array}{l}\text { Fundamentals of } \\
\text { Speech } \\
\text { Communications }\end{array}$ & $\begin{array}{l}\text { This course introduces students to principles of persuasion to } \\
\text { master clarity of oral and written ideas. The new module will } \\
\text { include assignments that critically examine and develop well- } \\
\text { researched arguments about the value of nanotechnology and its } \\
\text { future applications and development in various scientific fields. }\end{array}$ \\
\hline
\end{tabular}

Students in the TLC program attend seminar series about nanotechnology applications and research. The Introduction to Engineering Profession and to Engineering courses require students to conduct literature research, prepare reports, and present details on nanotechnology subjects that suite their interests. The Fundamental of Speech Communication course enables students to articulate their knowledge and understanding of nanotechnology. These three courses are required freshman engineering courses that prepare students for the remainder of the curricula. With the TLC structure, students achieve depth of knowledge before starting their four required courses for the track program.

\section{Assessment Results}

The survey data were collected from the students taking ENGR 195 freshman engineering course. This course constituted two sections. Nanotechnology-TLC program was implemented in one of the sections (indicated as Nanotechnology-TLC Cohort or TLC), while the second section did not take part in the program and did not take nanotechnology courses (indicated as Non-TLC Class or Non-TLC). Thus, the second section represents regular undergraduate freshman population. Table II shows comparative assessment results between Nanotechnology-TLC Cohort Non-TLC section. A score of 5 represent "strongly agree" and score of 1 represents "strongly disagree.” The higher level of knowledge about nanotechnology for the TLC group was because of the learning during the semester in the program. 
TABLE II: Course Survey within the Nanotechnology-TLC Freshman Cohort (25 Students) Compared with the Non-TLC Class.

\begin{tabular}{|l|l|l|}
\hline Survey Questions & $\begin{array}{l}\text { Nanotechnology- } \\
\text { TLC Cohort }\end{array}$ & Non-TLC Class \\
\hline $\begin{array}{l}\text { I have a good understanding of what nano- } \\
\text { technology is }\end{array}$ & 4.44 & 2.90 \\
\hline $\begin{array}{l}\text { I believe knowledge of nanotechnology will benefit } \\
\text { me in the future }\end{array}$ & 4.22 & 2.90 \\
\hline $\begin{array}{l}\text { I am aware of society issues that arise from the use } \\
\text { of nanotechnology }\end{array}$ & 3.95 & 3.55 \\
\hline $\begin{array}{l}\text { Doing the project increased my understanding of } \\
\text { nanotechnology (Non TLC was pursuing a another } \\
\text { course project, ECE196 project }\end{array}$ & 4.27 & 2.19 \\
\hline $\begin{array}{l}\text { Visiting the nanotechnology lab has given me a } \\
\text { better understanding of the research in this area }\end{array}$ & 4.33 & N/A \\
\hline $\begin{array}{l}\text { Working on nanotechnology paper/presentation has } \\
\text { increased my understanding of the field }\end{array}$ & 3.89 & N/A \\
\hline $\begin{array}{l}\text { The faculty presentations were helpful in increasing } \\
\text { my understanding of nanotechnology }\end{array}$ & 4.17 & N/A \\
\hline Nanotechnology will play important role in future & 4.61 & 4.1 \\
\hline
\end{tabular}

The performance of students in the 2013 and 2012 Nanotechnology-TLC was compared to that of students in three Non-TLC sections of ENGR195 freshman course. Performance indicators of attendance, completion of assignments, and course grades were used. It was found that attendance in class was much higher for students in the Nanotechnology-TLC. In the Nanotechnology-TLC Cohort, there were five absences during the Fall 2012 semester and 7 absences during the Fall 2013 semester. The non-TLC sections within the same course experienced higher absences. In the Nanotechnology-TLC the percentage of assignments submitted were 93\% in Fall 2012 and 92\% in Fall 2013. In the Non-TLC class, students submitted $89 \%, 83 \%$, and $82 \%$ of the assignments. There was also a difference in the course grades, as shown in Table III.

Table III: Comparison of course grades of students enrolled in Nanotechnology-TLC (TLC) and Non-TLC classes.

\begin{tabular}{|l|l|l|l|l|l|l|l|}
\hline & $\mathrm{A}$ & $\mathrm{B}$ & $\mathrm{C}$ & $\mathrm{D}$ & $\mathrm{F}$ & W & GPA (avg) \\
\hline TLC 2013 & 17 & 7 & 1 & 0 & 0 & 0 & 3.64 \\
\hline TLC 2012 & 18 & 2 & 2 & 1 & 0 & 1 & 3.6 \\
\hline Non-TLC 1 & 9 & 5 & 4 & 0 & 3 & 3 & 2.9 \\
\hline Non-TLC 2 & 11 & 5 & 1 & 1 & 5 & 2 & 2.7 \\
\hline Non-TLC 3 & 6 & 8 & 4 & 1 & 6 & 0 & 2.3 \\
\hline
\end{tabular}

In summary, the students in the Nanotechnology-TLC performed better, as evidenced by attending class more regularly, submitting more of the assignments, and attaining higher course grades. The highlights on the students' data over a sample of 50 students in the TLC program with a nanotechnology theme are given below 
1. $24 \%$ of the total students are from underrepresented groups.

2. Nearly $44 \%$ have decided to go to IUPUI to pursue nanotechnology, and were motivated through advisors and school recruitment tools.

3. $76 \%$ of the students expect that nanotechnology education will assist them with engineering and science curricula, prepare them for a nanotechnology career in industry, and provide them with research and hands-on experiences.

4. $44 \%$ of the students had some degree of pre-knowledge in nanotechnology before going to IUPUI.

5. Nearly $76 \%$ would like to pursue IUPUI's NSF-supported nanotechnology track.

Data collected after the semester indicate positive results that meet program objectives when covering advanced topics, research, hands-on experiences, and simulation software. A summary of student survey responses are as follows:

1. Students are primarily interested to pursue nanotechnology for application in Electronics, Defense/Military, Energy, Medicine, Vehicle Technologies, and Consumer Goods (listed based on rank).

2. Students have gained experiences in nanotechnology that they had not before joining the TLC.

3. The multidisciplinary nature of nanotechnology has assisted them with integrating knowledge from science and engineering.

4. Students enjoyed the seminar series in nanotechnology and are excited to visit nanotechnology labs within the school.

5. Nearly $50 \%$ are looking forward to conducting research in this area.

6. Generally, students are looking forward to pursuing advanced courses in nanotechnology with more hands-on learning.

7. Students in general are benefiting from literature research and report writing in the nanotechnology area.

\section{Outcomes and Conclusions}

The Nanotechnology track developed within the School of Engineering and Technology has proven successful in research and curriculum aspects. The inclusion of the nanotechnology-TLC contributed to the success of this track. Students' response to survey questions indicates the positive impact of the new modes of instructions used in the developed nanotechnology-TLC courses. The impact of the TLC was also observed in providing the freshman students with a good understanding of nanotechnology area. Freshman students in the nanotechnology-TLC performed better, as evidenced by attending class more regularly, submitting more of the assignments, and attaining higher course grades. In the Nanotechnology-TLC Cohort, there were five absences during the Fall 2012 semester and 7 absences during the Fall 2013 semester, which are lower in comparison to the non-TLC sections within the same course. The percentage of assignments submitted for the Nanotechnology-TLC groups were $93 \%$ and $92 \%$ compared to $89 \%, 83 \%$, and $82 \%$ for Non-TLC students. Additionally, the average grades for TLC students were 3.64 and 3.6 compared to 2.9, 2.7, and 2.3, respectively for Non-TLC students. The survey outcome indicated that $24 \%$ of the total students were from underrepresented groups, $76 \%$ of the 
students expect that nanotechnology education will assist them with future education and career, and nearly 76\% would like to pursue IUPUI’s NSF-supported nanotechnology track.

\section{ACKNOWLEDGEMENTS}

The authors would like to acknowledge support from National Science FoundationNanotechnology Undergraduate Education (NUE) grant 1042110.

\section{References:}

1. Raza H. and Raza T. Z., "Introducing Nanoengineering and Nanotechnology to the First Year Students Through an Interactive Seminar Course,” J. Nano Educ., vol. 4, pp. 41-46, 2012.

2. Zheng W., Shih H. R., Lozano K., Pei J. S., Kiefer K., and Ma X., "A Practical Approach to Integrating Nanotechnology Education and Research into Civil Engineering Undergraduate Curriculum,” J. Nano. Educ., vol. 1, pp. 22-33, 2009.

3. Mehta B. R., "Nano Education at Indian Institutes of Technology: A Status Report,” J. Nano. Educ., vol. 1, pp. 106-108, 2009.

4. Certificate in Nanotechnology and Nanoscience, George Mason University [Available: http://cos.gmu.edu/academics/graduate/certificates/certificate-nanotechnology-and-nanoscience].

5. Drexel University - BSc Materials Engineering with Specialization Nanotechnology [Available: http://www.materials.drexel.edu/Students/Undergrad/Tracks/].

6. Hadjilogiou, J., "The Engineering Curriculum for 2020: Values, Variability, Improvement and Knowledge,” 33rd Annual Frontiers in Education (FIE'03), vol. 3, pp.S3A19-26, 2003.I

7. Rizkalla, M. E. and Yokomoto, C. F., "Design of a Course in Semiconductor Device that Emphasizes Integration of Knowledge," Proceedings of the 2001 American Society for Engineering Education Annual Conference

8. Yokomoto, C. F., Rizkalla, M. E., O’loughlin, C. l., El-sharkawy, M. A., and Lamm, N. P., "Developing A Motivational Freshman Course In Using The Principle of Attached Learning,” Journal of Engineering Education, pp. 99-106, January 1999.

9. Rizkalla, M.E., Agarwal, M., Shrestha, S., Varahramyan, K, "Integration of Knowledge in Engineering/science Via Nanotechnology Programs,” 118th ASEE Annual Conference and Exposition, Vancouver, BC, 26 -29 June 2011.

10. Russell, S. H., Hancock, M. P., and McCullough, J., "Benefits of Undergraduate Research Experiences," Science, vol. 316, no. 5821, pp. 548-549, 2007.

11. Integrated Nanosystems Development Institute (INDI), Indiana University-Purdue University Indianapolis, Indiana [Available: http://www.indi.iupui.edu].

12. Center for Teaching and Learning, A Division of Office of the Vice Chancellor for Research, IUPUI [Available: $\underline{\text { http://crl.iupui.edu/]. }}$ 